\title{
Pengelolaan Sumber Daya Manusia \\ di Rintisan Sekolah Menengah Atas Bertaraf Internasional Majlis Tafsir Al-Qur'an (R-SMA-BI MTA) Surakarta
}

\author{
Ihlas $^{1}$, Sukrin $^{2}$, Aris Munandar ${ }^{3}$ \\ Prodi Pendidikan Islam Anak Usia Dini, Institut Agama Islam Muhammadiyah Bima ${ }^{12}$ \\ Sekolah Dasar Negeri 02 Suntu Kota Bima ${ }^{3}$ \\ Email: ihlashasan14@gmail.com ${ }^{1}$, babaraoht69@gmail.com ${ }^{2}$, \\ arismunandarndar643@gmail.com ${ }^{3}$
}

\begin{abstract}
ABSTRAK: Penellitian ini mengkaji tentang Manajemen Sumber Daya Manusia (MSDM) di Sekolah Menengah Atas Standar Internasional Majlis Tafsir Al-Qur'an Surakarta. Riset ini adalah riset kualitatif-etnografi yang menghasilkan data deskriptif. Ini dilakukan di R-SMABI MTA Surakarta Jawa Tengah. Studi ini merupakan penelitian kualitatif dengan etnografi ini berfokus pada budaya, perencanaan, penempatan dan atau pengembangan serta evaluasi Sumber Daya Manusia (SDM). Tujuannya, menggali model pengelolaan dan pengembangan SDM di R-SMA-BI MTA Surakarta. Temuan penelitian ini adalah: Pertama, budayanya sudah kondusif. Kedua, perencanaan SDM yang disesuaikan dengan analisis kebutuhan dengan kebutuhan penting seorang muslim, dan kondisi lain yang mendukung. Ketiga, beberapa penempatan sumber daya manusia tidak memenuhi kualifikasi akademik dan kompetensi. Sedangkan kualifikasi SDM belum memenuhi standar R-SMA-BI. Untuk kesehatan dan kesejahteraan SDM juga sudah diatur. Ketiga, evaluasi yang dilakukan pemerintah dan sekolah dengan berbagai model.
\end{abstract}

Kata Kunci: Pengelolaan, R-SMA-BI MTA, Sumber Daya Manusia

\begin{abstract}
This research examines the Human Resource Management in Senior High School of International Standard Majlis Tafsir Al-Qur'an Surakarta. This research is a qualitative-ethnographic research that produces descriptive data. This was done at R-SMABI MTA Surakarta, Central Java. This study is a qualitative study with ethnography focusing on culture, planning, placement and / or development and evaluation of Human Resources (HR). The goal is to explore the management and development model of human resources in RSMA-BI MTA Surakarta. The findings of this study are: First, the culture is conducive. Second, HR planning that is tailored to the needs analysis with the important needs of a Muslim, and other supportive conditions. Third, some human resource placements do not meet academic qualifications and competencies. Meanwhile, the qualifications of human resources have not met the R-SMA-BI standards. For the health and welfare of human resources it has also been regulated. Third, the evaluation conducted by the government and schools using various models.
\end{abstract}

Keyword: Administration, Human Resources Masnagament, R-SMA-BI MTA. 


\section{PENDAHULUAN}

Marshall McLuhan (1960-an)

mengistilahkan peradaban sekarang seperti kampung global (global village). Perkembangan teknologi informasi (information tecnologi) selain membawa pesan positif bagi ummat manusia, juga telah menghilang batas dan kedaulatan negara. Miliaran manusia di seluruh penjuru dunia dapat mengakses informasi negara lain tanpa dipersilahkan sekalipun. Realita ini memaksa bangsa Indonesia sebagai kontestan peradaban global untuk menciptakan potensi SDM yang berkualitas sebagai benteng perisai bangsa. Jika tidak, maka keberadaan Indonesia di panggung internasional akan tertinggal dan tidak diperhitungkan bangsa lain.

Namun menciptakan SDM yang berkulitas bukanlah perkara sederhana. Peringkat Human Devolopment Index (HDI) yang rilis oleh UNDP melaporkan Indonesia berada pada urutan yang cukup rendah. Padahal SDM berkualitas merupakan kunci dalam meningkatkan daya saing suatu bangsa. Maka penyelenggaran pendidikan bangsa ini perlu segera dibenahi

Sebab salah satu elemen yang diyakini mampu medongkrak kualitas SDM adalah pendidikan. Hingga kini, pendidikan masih dipercaya sebagai media yang sangat ampuh dalam membangun kecerdasan anak bangsa. Sehingga pemerintah meluncurkan program Rintisan Sekolah Mengengah Atas Bertaraf Internasional (R-SMA$\mathrm{BI}$ /sederjat). Namun hadirnya R-SMA-BI (walaupun sudah dibubarkan) sepertinya perlu dibarengi dengan pengelolaan tenaga pendidik dan kependidikan yang baik. Menurut Khan (2010: 165) perbaikan pengelolaan SDM dimulai dari proses rekrutmen dan seleksi, pelatihan dan pengembangan, penilaian kinerja, kompensasi dan penghargaan, serta meningkatkan kompetensi dan kualifikasi guru dan staf.

Fungsi pokok pengelolaan yaitu, planning, actuating/organizing dan controling. Sekolah sebagai sumber pendidikan yang di dalamnya terdapat SDM, harus dikelola dengan profesional. Keberhasilan sebuah sekolah sangat ditentukan oleh kepala sekolah dalam memberdayakan seluruh warga sekolah, termasuk pembinaan dan pengembangan guru dan staf.

Selain kepala sekolah, tenaga pendidik (guru) merupakan elemen penting di sekolah yang harus diperhatikan. Tenaga pendidik merupakan tenaga profesional yang bertugas merencanakan dan melaksanakan proses pembelajaran, menilai hasil pembelajaran, melakukan pembimbingan dan pelatihan, serta melakukan riset dan pengabdian kepada masyarakat terutama bagi pendidik perguruan tinggi, (UU Sisdiknas No. 20. Tahun 2003).

Sementara tenaga kependidikan (teknisi kependidikan, laboran, teknisi sumber belajar, tenaga administratif dan pegawai honorer) juga merupakan komponen yang ikut membantu keberhasilan sebuah sekolah. Tenaga kependidikan adalah anggota masyarakat yang mengabdikan diri dan diangkat untuk menunjang penyelenggaraan pendidikan.

Sehingga uraian di atas menjadi realitas pendorong untuk dilakukan riset ilmiah tentang "Pengelolaan SDM Rintisan Sekolah Menengah Atas Bertaraf Internasional Majlis Tafsir Al-Qur'an Surakarta". Riset ini bertujuan untuk menggali model manajemen dan pengembangan SDM pada R-SMA-BI MTA Surakarta.

\section{METODE PENELITIAN}

Riset ini adalah riset kualitatifetnografi yang menghasilkan data 
deskriptif. Ini dilakukan di R-SMABI MTA Surakarta Jawa Tengah, dengan lama riset 1 s/d 2 bulan (Agustus-Oktober 2012). Dengan subyek riset antara lain; penanggungjawab yayasan R-SMABI MTA Surakarta, Kepala Sekolah, Wakil Kepala Sekolah, guru, siswa, penanggungjawab sarana dan prasaran (sarpra), bendahara, dan komite Sekolah R-SMABI MTA Surakarta.

Beberapa jenis sumber data secara menyeluruh yang dapat dikelompokan; pertama, narasumber (informan), kedua, peristiwa atau aktifitas. Ketiga dari benda, beragam gambar, dan rekaman. Keempat, dokumen dan arsip.

Prosedur dan instrumen dalam pengumpulan data meliputi; observasi, wawancara, analisis isi, dan skala obyektif. Sementara teknik pengumpulan data dalam riset ini; pertama observasi, meliputi seluruh sarana dan prasarana, kondisi lingkungan, dan kultur R-SMABI MTA. Instrumen pendukung adalah form observasi, instument wawancara dan kamera. Kedua, wawancara dengan dua model; wawancara terarah dan wawancara tidak terarah. Ketiga, dokumentasi yakni catatan peristiwa yang sudah berlalu berupa tulisan dan gambar. Keempat, teknik mencatat yakni menyusun catatan lapangan yang bersumber dari informen. Kelima, teknik rekaman yaitu merekam meteri pembicaraan informen yang ada di RSMABI MTA Surakarta. Kemudian dilakukan analisis yang dengan rangkaian, pengumpulan data, reduksi data, sajian data, dan penarikan simpulan dan verifikasi.

\section{HASIL DAN PEMBAHASAN}

Kehadiran program R-SMA-BI yang diluncurkan pemerintah ternyata menuai beragam tanggapan. Di satu sebagian sisi publik menaruh ekspektasi yang cukup tinggi, sementara pada kondisi yang bersamaan banyak masyarakat yang menolak kehadiran R-SMA-BI karena dianggap bertentangan dengan konstitusi negara dan akhirnya Mahkamah Konstitusi (MK) membubarkannya. Meski demikian, program R-SMA-BI sempat berjalan sampai tahun 2012 lalu (sebelum riset ini berakhir).

Pro-konta itulah yang mendorong peneliti melakukan riset di R-SMA-BI MTA Surakarta. Namun riset ini tidak mengkaji secara komprohensif komponen penyelenggaraan R-SMA-BI. Riset ini hanya dibatasi pada kajian aspek kultur dan pengeloloaan guru dan staf yang ada di SMA MTA.

\section{Sekilas tentang Sejarah dan Kultur R- SMA-BI MTA Surakarta}

R-SMABI MTA merupakan salah satu lembaga pendidikan swasta yang hadir melengkapi kekurangan pendididikan bangsa Indonesia pada saat itu. Yayasan MTA menganggap urgen untuk dihadirkannya sekolah yang berhaluan Islam. Menurut mereka, salah satu cara untuk memperbaiki akhlak dan moral generasi adalah menanamkan nilainilai Islam dalam setia diri manusia. Selain itu, SMA MTA lahir untuk menjawab kerisauan yang dialami oleh warga MTA pada saat itu. Sebab pada era Orde Baru berkuasa, gadis-gadis muslimah susah mengenakan busana muslim ketika berada di sekolah. Sehingga Yayasan MTA bersama warganya sepakat untuk mendirikan lembaga pendidikan sendiri.

Seiring berjalannya waktu, proses pendidikan di sekolah tersebut kian hari terus dibenahi. Berdasarkan data yang terkumpul dilapangan, nuasa keramahan dan sopan santun merupakan keunggulan yang sangat menonjol di R-SMABI MTA Surakarta. Begitupun dalam ruangan kelas, selama kunjungan kelas maupun waktu istirahat (di luar kelas) budaya sopan santun dan budaya keramahan sangat terlihat. Tegur sapa yang santun antara guru, murid dan warga sekolah 
terlihat begitu 'intim'. Budaya keislaman dan saling menghargai (egaliterian), menjadi ciri khas warga sekolah tersebut. Kultur yang kondusif, islamis dan iklim pendidikan yang kompetitif sangat terasa dan terlihat.

Suasana dalam kelas sangat kondusif. Hal ini dapat dilihat dari sikap guru dan siswa/i yang hampir semuanya menunjukkan kematangan baik dalam berinteraksi maupun dalam berkomunikasi saat melakukan presentasi di dalam kelas. Selain itu kebersihan, ketenangan, dan lingkungan tanpa asap rokok juga telah memenuhi kultur yang diharapkan. Artinya bahwa SMA MTA telah memenuhi standar kultur sebagai sekolah R-SMABI. Sebab menurut pengakuan piahk sekolah, ciri khas dari program R-SMA-BI yang diunggulkan oleh SMA MTA adalah kemulian moral dan akhlak warga sekolah (guru, staf dan peserta dididk), disamping kualitas matapelajaran umum juga tetap ditingkatkan.

Sementara sarana dan prasarana $\mathrm{R}$ SMA-BI MTA secara umum telah melengkapi semua fasilitas yang dibutuhkan. Seperti laboratorium, perpustakaan, tempat ibadah, kantin, koperasi guru/pegawai, dan fasilitas lain termasuk asrama sebagai sarana pembinaan siswa. Tetapi disisi lain, proses digitalisasi kegiatan pembelajaran masih belum diterapkan secara menyeluruh. Meskipun sebagian besar dari SDM yang ada sudah mampu memanfaatkan Information Communication and Technologi (ICT).

\section{Model Perencanaan SDM di R-SMA-MTA Surakarta}

Perencanaan sumber daya
manusia akan memperbaiki
pemberdayaan SDM, memadukan
kegiatan-kegiatan personalia dan tujuan
organisasi di waktu yang akan datang
secara efisien, melakukan pengadaan

pegawai baru secara ekonomis, mengembangkan informasi dasar manajemen untuk membantu kegiatankegiatan unit-unit organisasi lainnya, membantu program penarikan dan dasar tenaga kerja secara sukses, serta mengkoordinasikan program-program manajemen personalia yang berbedabeda (Hasibuan, 2005; Nasir, dkk, 2020). Hal ini akan membawa suatu instansi kepada hasil kerja yang optimal karena terdapat adanya korelasi positif antara penempatan pegawai dengan peningkatan produktifitas kerja.

Meskipun kultur R-SMA-BI MTA sudah sesuai standar. Namun dalam aspek lain,peneliti menjumpai beragam temuan, baik hal-hal yang sudah sesuai dengan rancang bangun desain pemerintah pusat maupun fakta lain yang perlu disikapi secara serius. Sehingga RSMA-BI tidak teresan hadir sebagai program latah dari negara lain, melainkan menjadi prolem solver pendidikan kita.

Dalam kaitannya dengan perencanaan SDM R-SMA-BI MTA, yayasan dan pihak sekolah sepakat menentukan standar dan kriteria wajib bagi SDM yang akan diserap. Wawasan keislaman (warga MTA sendiri) dan akhlak yang paripurna menjadi syarat sakral dan penting diprioritaskan. Disamping tes wawancara, tes psikologi, dan tes kemampuan akademik juga sangat diperhatikan. Namun hal itu baru diterapkan mulai tahun 2012 lalu. Sebab dari 61 guru dan 19 tenaga kependidikan, hanya beberapa orang yang melewati tes resmi, karena alasan kondisional pada awal perintisan sekolah MTA.

Untuk perekrutan guru dan staf, pihak yayasan juga melibatkan pihak sekolah untuk melakukan identifikasi kebutuhan. Dari hasil identifikasi itu, sekolah mengusulkan ke yayasan dan selanjutnya yayasan yang akan melakukan perekrutan. Mekanisme ini sesuai dengan prinsip yang dikemukakan 
oleh Siagian (2006: 103), dalam proses perekrutan setidaknya memperhatikan para pencari tenaga kerja baru perlu dikaitkan dengan hasil indentifikasi lowongan kerja yang dibutuhkan.

Bila pihak yayasan ingin merekrut SDM (guru) baru yang memiliki kualitas mumpuni. Biasanya diinformasikan melalui siaran radio milik MTA sendiri. Masyarakat yang memiliki kriteria dan memenuhi syarat sesuai yang diharapkan oleh pihak sekolah MTA, bisa mendaftarkan diri. Bila mampu melewati rangkaian tes yang telah ditetapkan, maka yang bersangkutan akan ditetapkan menjadi guru di sekolah tersebut.

\section{Penempatan dan Pengembangan SDM R- SMABI MTA Surakarta}

Mathis \& Jackson (2006: 262) menyatakan bahwa penempatan adalah menempatkan posisi seseorang ke posisi pekerjaan yang tepat, seberapa baik seorang karyawan cocok dengan pekerjaanya akan mempengaruhi jumlah dan kualitas pekerjaan. Penempatan penting karena penempatan pegawai berpengaruh terhadap kinerja pegawai

Secara umum penempatan tenaga pendidik dan kependidikan di R-SMABI MTA sudah sesuai dengan standar kualifikasi SDM yang ada. Namun terdapat beberapa guru yang masih rangkap jabatan, tetapi itu tidak menghambat proses pelaksanaan kegiatan kependidikan. Diakui oleh beberapa informen, penempatan SDM yang ada di sekolahnya masih belum mampu profesional. Sebab SDM yang ada adalah warga yang mengabdi secara ikhlas di yayasan.

Sementara masalah kompetensi juga masih dibawah standar, seperti kemampuan berbahasa Inggris. Jangankan tenaga kependidikan yang diharapkan dapat berbahasa Inggris. Guru saja yang diharuskan menyajikan materi pelajaran dengan pengantar berbahasa Inggris, justru tidak dapat berkomunikasi bahasa Inggris dengan aktif. Padahal pemerintah telah menetapkan standar minimal SDM di R-SMA-BI menguasai bahasa Inggris. Sehingga sampai riset ini berakhir, pembelajarannya masih menggunakan bahasa Indonesia. Bahkan sebagian guru mengakui, penggunaan bahasa Inggris hanya mempersulit penyampaian materi pelajaran.

Selain itu beberapa personil masih ada yang merangkap tugas. Walaupun mereka mengakui tidak ada kendala terkait hal itu. Tetapi idealnya rangkap tugas di R-SMA-BI sedapat mungkin dihindari karena mengurangi profesionalisme kerja. Karena pada hakikatnya, penempatan tanaga kerja baru, harus diperhatikan kualifikasi dengan kemampuan yang dimilikinya.

Meski penempatan SDM di RSMABI MTA belum sepenuhnya tepat. Sekitar 15\% dari total guru yang ada telah memenuhi standar kualifikasi R-SMABI. Secara berkelanjutan pihaknya tengah menyekolahkan beberapa orang guru ke jenjang magister. Untuk pembiayaannya, yayasan mengucurkan sejumlah dana baik dari anggaran block grant maupun dari RAPBS gunakan untuk membantu guru yang melanjutkan study.

Penentuan guru yang akan melanjutkan study magister itu dilihat dari jenjang karier, senioritas, pengalaman, umur dan yang lebih penting lagi kualifikasi akademik. Sejauh ini, yayasan MTA masih memprioritaskan guru MIPA untuk melanjutkan study, juga yang berkulaifiasi lain tetap diperhatikan. Diakui sejumlah informen, dalam setiap penerapan kebijakan di sekolah tersebut sejauh ini tidak ada indikasi diskriminasi, semunya berjalan sesuai adanya.

Sementara standar kesejahteraan bagi SDM juga tetap diperhatikan. 
Sejumlah responden mengakui gaji yang mereka peroleh insyaAllah sudah mampu mencukupi. Selain itu mereka juga punya dan pensiun dan tabungan rahasia yang pada waktu tertentu akan diambil/diserahkan oleh pihak sekolah. Pihak sekolah juga memiliki asuransi kesehatan bagi warga sekolah. Bila ada yang sakit atau melahirkan, sebagian biaya akan ditanggung oleh pihak sekolah sesuai aturan yang telah disepakati.

Namun pihak sekolah tidak menjelaskan secara detail berapa besaran gaji guru dan staf di R-SMA-BI MTA Surakrta. Apakah sudah sesuai dengan standar upah minimun regional (UR) Surakarta. Selain itu penggunaan dana block grant untuk pengembangan SDM R-SMA-BI dijumpai masih belum efektif dan tidak tepat sasaran. Apalagi pagu anggaran untuk pembiayaan RSMABI sangat jelas, mulai dari pemerintah (pusat, provinsi dan daerah), masyarakat dan perusahaan yang tidak mengikat. Sehingga dengan anggaran itu sebenarnya dapat dipergunakan untuk pengembangan sekolah dan pemenuhan gaji guru dan staf.

\section{Model Evaluasi SDM R-SMA-BI MTA Surakarta}

Terkait keberadaan SDM, pihak sekolah dan yayasan bersama pemerintah aktif melakukan evaluasi secara berkala. Pemerintah melakukan monitoring dan evaluasi (monev) satu kali setahun. Ini dilakukan untuk mengetahui tahapan dan capaian yang telah diraih oleh sekolah tersebut. Begitupun dengan pihak sekolah sendiri juga aktif melakukan evaluasi seperti supervisi secara berkala.

Selain supervisi berkala yang dilakukan oleh kepala sekolah. Pengajian rutin menjadi salah satu cara jitu untuk mengevaluasi perkembangan sekolah sekaligus sebagai wadah penyelesaian masalah internal sekolah. Pengajian rutin yang diselenggarakan oleh pihak yayasan menjadi moment yang dianggap tepat untuk memberikan motivasi kerja bagi guru dan staf, dan itu sangat terbukti mampu menggerakkan SDM yang ada di sekolah tersebut.

Jika dalam evaluasi ditemukan guru atau staf yang bermasalah, maka pihak yayasan memberikan sanksi tegas seperti dikeluarkan dari sekolah jika diperlukan. Sebaliknya bila ada guru atau staf yang memiliki kinerja dan prestasi yang bagus, maka akan mendapatkan penghargaan dari pihak sekolah atau yayasan. Baik itu berupa promosi jabatan, pemberian hadiah maupun hal-hal lain yang dapat mendorong semangat kerja bagi guru dan staf sehingga mereka bisa lebih kreatif dalam mengembangkan tugas yang diamanahi.

\section{SIMPULAN}

Menelaah kembali pembahasan di atas, ada beberapa hal yang dapat disimpulkan. Secara umum, masih perlunya pihak R-SMABI MTA Surakarta menyesuaikan dengan aturan menyelenggarakan R-SMABI Nasional. Seperti perencanaan, perekrutan, penempatan, hingga dalam proses evaluasi sumber daya manusia (SDM).

Proses perencanaan guru dan staf yang ada di sekolah tersebut masih belum sepenuhnya memenuhi tuntutan peraturan sebagai R-SMABI, hal itu bisa dilihat dari beberapa indikator seperti, tenaga pendidikan dan kependidikan masih banyak yang belum memenuhi standar kualifikasi akademik.

Namun demkian, sekolah tersebut tetap berusaha merubah diri, baik dari aspek proses, maupun pelaksanaan perencanaan. Namun harus diakui, RSMABI MTA Surakarta masih jauh lebih baik bila dibandingkan dengan sekolah lain yang sudah mengantongi ijin RSMABI. Hal itu ditandai dengan dimulainya penerapan seleksi dan perekrutan tenaga pendidikan dengan 
beberapa persyaratan yang lebih profesional. Disamping itu kultur sekolah yang benar-benar religius, dan sangat nyaman untuk kegiatan kependidikan

Sebagaimana diakui oleh sejumlah responden guru, secara umum penempatan tenaga pendidik R-SMABI MTA sudah sesuai dengan standar kualifikasi dan kompetensi akademik. Namun terdapat beberapa guru yang merangkap menjadi staf. Meskipun diakui oleh guru yang bersangkutan, sama sekali tetapi tidak mengganggu tugas lain, dan semuanya lancar saja.

Selain itu kualifikasi tenaga pendidik masih belum memenuhi standar penyelenggaraan R-SMABI. Sebab merujuk apada aturan peyelenggaraan, tanaga pendidik yang mengajar di RSMABI minimal $30 \%$ S2 atau S3. Begitupun halnya dengan kepala sekolah, harus memenuhi standar kualifikasi sebagaimana tersebut. Sementara hasil temuan, dari 61 orang guru, hanya sekitar $15 \%$ yang sudah memenuhi kualifikasi magister. Begitu halnya dengan tenaga kependidikan, tingkat kualifikasi dan kompetensinya masih belum memenuhi syarat sebagai R-SMABI.

Evalusi SDM yang ada di R-SMABI MTA tidak jauh beda dengan pola evaluasi yang dilakukan oleh sekolah lain. Namun R-SMABI MTA memiliki model evaluasi yang nilai religiusnya cukup representatif. Evaluaisi tersebut adalah digelarnya pengajian rutin tiap awal bulan. Selain itu guru dan staf yang ada di R-SMABI MTA juga diwajibkan mengikuiti pengajian yang selenggarakan oleh yayasan pusat setiap satu kali sepekan. Supervisi dan evaluasi juga tetap dilakukan oleh pemerintah.

Dengan meneropong uraian masalah yang dikupas sebelumnya, maka hasil riset ini membawa beberapa implikasi antara lain; standar kultur sebagai sekolah R-SMABI sudah dipenuhi oleh SMA MTA. Tinggal sarana dan prasarana sesuai standar RSBI diusahakan dilengkapi. Bila ketentuan R-SMABI mewajibkan bagi kepala sekolah, dan guru minimal 30\% guru berkualifikasi S2 dari populasi yang ada. Maka pihak yayasan harus mempercepat penyekolahan guru-guru yang ada. Jika tidak maka kesempatan melanjutkan program ke sekolah bertaraf Internasional tidak dapat terpenuhi.

Selain itu, jika SDM sudah memenuhi, rangkap jabatan sedapat mungkin dihindari, demi terciptanya iklim yang profesional. Dari hasil supervisi dan evaluasi dari pemerintah bahwa R-SMABI MTA belum pernah mendapatkan prestasi dalam pentas internasional, maka saatnya untuk meningkatkan semangat kompetitif, tidak hanya siswa, guru juga wajib menujukan prestasi baik akademik maupun non akademik. Dan model evaluasi yang dilakukan oleh pihak sekolah perlu dipertahankan dan dikembangkan, karena itu cukup sukses.

Selanjutnya, lewat kesempatan ini peneliti memberikan beberapa saran kiranya perlu diperhatikan, baik bagi sekolah maupun bagi pemerintah. Bagi yayasan dan sekolah R- SMABI MTA Surakarta. Secara keseluruhan, pengelolaan SDM yang ada di R-SMABI sudah mulai memperlihatkan tandatanda pemenuhan syarat sebagi sekolah R-SMABI. Namun beberapa hal yang harus terus didorong, pertama peningkatan kualifikasi guru dan tenaga kependidikan harus tetap dilakukan. Kedua, aspek administrasi perlu ditata dan ditertibkan lagi, sebab terdapat kesulitan bagi peneliti ketika membutuhkan data-data tertentu. Ketiga, perlunya profesionalitas dalam bekerja dan tidak semata mengandalkan kepercayaan.

Untuk pemerintah terkait, dari hasil riset tentang pengeloaan SDM di R$S M A B I$, ditemui banyak kelemahan yang semestinya ini menjadi tanggung jawab 
pemerintah. Seperti masih kurangnya evaluasi terhadap keberadaan programprogram yang dilakukan oleh sekolah terkait.

Perlunya penegasan tentang penggunaan paket anggaran block grant yang telah dikucurkan bagi sekolah yang mengantongi ijin R-SMABI, sehingga memenuhi sasaran yang telah diinginkan oleh pemeintah. Sebab dijumpai di lapangan, masih lemahnya pengawasan dan bimbingan pemerintah terkait program-program R-SMABI, serta pelunya menjelaskan kembali apa bedanya R-SMABI dengan SMA biasa. Sebab masih beravariasinya tafsir tentang sekolah bertaraf internasional.

\section{UCAPAN TERIMKASIH}

Penulis menghaturkan terimakasih kepada semua pihak yang telah membantu menyusunan tulisan ini. Penulis juga menyampaikan penghargaan kepada tim editor JET FKIP UM Kendari atas kesediaannya menyediakan wadah bagi kami untuk mempublikasi tulisan ini.

\section{DAFTAR PUSTAKA}

Ali, Muhammad. (2012). Menyemai Sekolah Bertaraf Inernasional. Cetakan Pertama, Yogyakarta; Suara Muhammadiyah Yogyakarta Harian Umum Kompas.

Fadilah, N. Asri, Hamik, Abdul, dan Siswidiyanto. (2013). Pengaruh Penempatan Pegawai Terhadap Kinerja (Studi pada Pegawai Sekretariat Daerah Kabupaten Gresik). Jurnal Administrasi Publik (JAP), Vol. 1, No. 5, Hal. 847-852.

Hasibuan, Malayu S.P. (2005). Manajemen Sumber Daya Manusia. Jakarta: Bumi Aksara.

Mathis, L.R dan J.H Jackson. (2006) Manajemen Sumber Daya Manusia (Human Resource Management). Jakarta: Salemba Empat.
Nasir, Adam, M. Rahmawati. M, Arfin, Mujiati, dan R. Titin. (2020). Manajemen Sumber Daya Manusia: Pengadaan dan Retensi SDM di Perguruan Tinggi Swasta (Teori Dan Praktek). Bandung: Alfabeta.

Panduan Penyelenggaraan Rintisan Sekolah Menengah Atas Bertaraf Internasional. (2010). Kemendiknas Dirjen Mendikdasmen Pembinaan Sekolah Menengah Atas.

Sugiyono. (2011). Metode Penelitian Pendidikan. Edisi Ke-13. Bandung: Alfabeta

Sutama. (2011). Metode Penelitia Pendidikan. Cetakan Kedua, Surakarta: Fairuz Media

Spradley, James. P. (2007). Metode Etnografi. Edisi Kedua; Yogyakarta: Tiara Wacana.

Undang-undang Sistem Pendidikan Nasional No. 20 Tahun 2003. 